\begin{tabular}{|c|c|c|}
\hline & International Journal of Current Research in & \\
\hline & $\begin{array}{c}\text { Biosciences and Plant Biology } \\
\text { ISSN: 2349-8080 }\end{array}$ & $\begin{array}{lll}0 \\
0\end{array}$ \\
\hline $\begin{array}{l}\text { PAE } \\
\text { PUBB }\end{array}$ & Journal homepage: www.ijcrbp.com & \\
\hline
\end{tabular}

\title{
Application of CERES-Rice Model to Identify Optimum Sowing Window for Different Rice Varieties under Aerobic Culture
}

\author{
${\text { Banoth Balaji Naik }{ }^{*} \text {, Gade Sreenivas }}^{2}$, Danda Raji Reddy ${ }^{3}$ and Padamati Leela Rani ${ }^{4}$ \\ ${ }^{1}$ Scientist (Agronomy), Agro Climate Research Centre, Agricultural Research Institute, Rajendranagar, Hyderabad -50o o30, \\ India \\ ${ }_{2}^{2}$ Director, Agro Climate Research Centre, Agricultural Research Institute, Rajendranagar, Hyderabad -5oo o3o, India \\ 3 Director of Research, Administrative Office, Prof. Jayashankar Telangana State Agricultural University, Rajendranagar, \\ Hyderabad -50o o3o, India \\ 4Senior Scientist (Agronomy), AICRP on Weed Control, Water Technology Centre, Rajendranagar, Hyderabad -5oo o3o, India
}

*Corresponding author.

\begin{abstract}
A bstract
Planting window concept is a useful approach in identifying suitable planting time and appropriate varieties to ensure crop success under aerobic irrigated rice conditions. CERES-Rice model was validated with experimental data collected during kharif 2012 and 2013 to ensure its fitness in the region in order to simulate the growth and development of rice varieties under aerobic environment of Telangana State and to determine the impact of various sowing windows and different duration group rice varieties on grain yield. The simulation scenarios showed that under irrigated aerobic conditions, $17^{\text {th }}$ June sown crop predicted the highest average grain yield of $5689 \mathrm{~kg} \mathrm{ha}^{-1}$ and it was on par up to $29^{\text {th }}$ June sown crop. The median yield decreased consistently with each delay in time of sowing. Among the varieties the extra short duration $c v$ JGL 17004 and short duration $c v$ MTU 1010 have wider sowing window with highest grain yield at $8^{\text {th }}$ July and $1^{\text {st }}$ Julysowings respectively. Whereasthe medium duration $c v$ JGL 11470 and long duration $c v$ MTU 1061 have narrow sowing window from $10^{\text {th }}$ June to $1^{\text {st }}$ July with highest grain yield when sown on $10^{\text {th }}$ June. Based on seasonal analysis, it was identified the optimum sowing window for extra short and short duration cultivars was wider from $10^{\text {th }}$ June to $26^{\text {th }}$ August where as for medium and long duration cultivars was narrow from $10^{\text {th }}$ June to $1^{\text {st } J u l y ~ t o ~ o b t a i n ~ o p t i m u m ~ g r a i n ~ y i e l d s ~ u n d e r ~ a e r o b i c ~}$ environment.
\end{abstract}

\section{Introduction}

Rice is the staple food in Asia but also the single biggest user of fresh water. More than $80 \%$ of the developed fresh water resources in Asia are used for irrigation purposes and consumes up to $43 \%$ of the world's developed irrigation resources (Bouman et al., 2007). About 22 million hectares of irrigated dry season rice experience "economic water scarcity" in South and South-East Asia (Tuong and Bouman, 2002). The

\section{Article Info}

Accepted: 29 March 2016

Available Online: 06 April 2016

Ke ywords

Aerobic rice

CERES-rice

DSSAT tools

Sowing window

Rice varieties common method of rice cultivation in India is transplanting the nursery which is very laborious, water and time consuming. The high cost of farm labour invariably delays transplanting and often leads to the use of aged seedling. To address these problems, growing rice under aerobic soil conditions is evolved. Aerobic rice offers such advantages as faster and easier planting, could be successfully cultivated with 600 to $700 \mathrm{~mm}$ of total water in summer and entirely on rainfall in wet season (Hittalmani, 2007a, 2007b) and reduced labour 
cost, and often higher profit in areas with an assured water supply. However, at the same time, no varieties have been specifically developed for this purpose. The existing varieties used for rice culture do not appear to be well adapted for growth and yield. There is a little intervention which has been made so far on suitability of existing rice varieties to aerobic method of cultivation under varied dates of sowing as per the situation. However, this process is time consuming and expensive as many years of experimental trials are required.

Planting window concept sometimes called as the growing period concept and was first introduced by Cocheme and Franquin (1967). The concept was defined by Andrade et al. (2009), in general, there are interactions between various factors that affect crop growth, development and yield, whose individual effect is difficult to quantify. Modeling can be a useful tool for studying this kind of problem. The application of systems analysis that combines both experimental field research and crop modeling to determine optimum farming practices in different countries has become common. This study aimed to use Decision Support System for Agrotechnology Transfer (DSSAT) seasonal tool to set a sowing window and suitable varieties by using 20 years historical daily weather data from 1984 to 2013 for irrigated rice crop under aerobic condition at farm level.

\section{Materials and methods}

The study was divided into three phases. In the first phase the genetic coefficients for different duration group rice varieties viz., JGL 17004 (105 days), MTU 1010 (120 days), JGL 11470 (135 days) and MTU 1061 (160 days) were derived. In the second phase, the model predictive capability was verified with experimental data from a farm located at Agriculture Research Station, Madhira situated at an altitude of $189 \mathrm{~m}$ above mean sea level at $16^{\circ} 53^{\prime} \mathrm{N}$ latitude and $80^{\circ} 22^{\prime} \mathrm{E}$ longitude in India during kharif seasons of 2012 and 2013 under irrigated conditions. In the third phase, model's seasonal module was used to simulate scenarios of sowing dates and varieties in order to define the best sowing window for different duration group varieties of aerobic rice under irrigated situation.

\section{Development of genetic coefficient}

A field experiment was conducted for two consecutive seasons of kharif, 2012 and 2013 at Agriculture Research Station, Madhira. The soil of the experiment sites was clay in texture, saline in reaction. The rice cultivars were managed under optimum conditions to allow it to express its genetic potential under current weather conditions. Data collection and genetic coefficients adjustments were done according to the procedures described by Hunt and Boote (1998) by using first two date sown crop $\left(18^{\text {th }}\right.$ June and $7^{\text {th }}$ July $)$ during which the crop growth and yields were higher in both the years of study. Derived genetic coefficients for the rice varieties were added to DSSAT's genotype file to be used in other simulations.

\section{Model predictive capability/ validation}

In the second phase of the study, the model's predictive capability was verified by comparing simulated grain yield with observed rice grain yield from later three dates ( $20^{\text {th }}$ July, $4^{\text {th }}$ August and $18^{\text {th }}$ August) sown crop which obtained from experimental data. Validation of CERESRice model confirmed that, the model can be used as a research tool in the variable agro-environments of Telangana State to suggest suitable sowing window for different duration group rice varieties.

\section{Aerobic rice yield seasonal and temporal variability analysis}

The third step of the study consists of applying the CERES-Rice model seasonal tool to evaluate the performance of varieties under different dates under irrigated aerobic conditions. The model was set to simulate 48 different scenarios (treatment combinations; 12 sowing dates $\times 4$ varieties) starting from $10^{\text {th }}$ June to $26^{\text {th }}$ August at weekly interval and four rice varieties viz., JGL 17004 MTU 1010, JGL 11470 and MTU 1061 under aerobic conditions of semiarid environment for 20 years using historical daily weather data from 1984 to 2013. Twenty years of records was used with model's seasonal tool to generate 20 values of simulated grain yield for each one of the 12 sowing weeks and 4 varieties, which were plotted as a box plot frequency distribution and as average yield values versus variance.

The data were analyzed statistically applying one way analysis of variance technique using SAS. The significance was tested by ' $F$ ' test (Snedecor and Cochron, 1967). Critical difference for examining treatment means for their significance was calculated at 5 percent level of probability $(p=0.05)$. In order to analyze the pattern of difference between means Fisher's least significant difference test ( $t$ test) was employed (Hayter, 1986). 


\section{Results and discussion}

Simulation results of aerobic rice sown under different dates subjected to one way analysis of variance and means were compared with Tukey's HSD test and presented in the Table 1 and depicted in Fig. 1. The simulation scenarios showed that under aerobic conditions $10^{\text {th }}$ June sown crop predicted the highest average grain yield $\left(5752 \mathrm{~kg} \mathrm{ha}^{-1}\right)$ and it was on par with the crop sown from $17^{\text {th }}$ June to $29^{\text {th }}$ July and $19^{\text {th }}$ August to $26^{\text {th }}$ August. Optimum sowing window for aerobic rice considered from $10^{\text {th }}$ June to $29^{\text {th }}$ July and $19^{\text {th }}$ August to $26^{\text {th }}$ August with the highest median value of grain yield $5752 \mathrm{~kg} \mathrm{ha}^{-1}$ obtained in 10 June sown crop. The model assumes that, there was no significant difference in grain yield of aerobic rice with every successive one week delay in sowing from $10^{\text {th }}$
June to $29^{\text {th }}$ July and $19^{\text {th }}$ August to $26^{\text {th }}$ August. The median yield decreased consistently with every one week delay in sowing from $10^{\text {th }}$ June to $12^{\text {th }}$ August and increased there after steadily up to $26^{\text {th }}$ August. However, the reduction in grain yield was significant from $5^{\text {th }}$ August to $12^{\text {th }}$ August sowings when compared to $10^{\text {th }}$ June sown crop. But in real sense it was not true, as the experimental results showed that, significantly more grain yield was realized up to $7^{\text {th }}$ July sown crop and reduced thereafter with every successive 15 days delay in sowing up to $18^{\text {th }}$ August during 2012 and 2013. However, the box plots (Fig. 1) showed that $8^{\text {th }}$ July sown crop was considerably less variable than all other dates and consequently, smaller variance was associated to its average yield. Further this reduced variability gave the least downside risk (risk of achieving low yields).

Table 1. Tukey's (HSD) test for mean grain yield $\left(\mathrm{kg} \mathrm{ha}^{-1}\right)$ of aerobic rice under different dates of sowing.

\begin{tabular}{llll}
\hline Date & Grain yield $\left(\mathbf{k g ~ h a}^{-\mathbf{l}}\right)$ & Tukey- Grouping & \\
\hline 10-June & 5752 & & A \\
17-June & 5689 & B & A \\
24-June & 5639 & B & A \\
01-July & 5581 & B & A \\
26-August & 5517 & B & A \\
08-July & 5488 & B & A \\
15-July & 5426 & B & A \\
22-July & 5359 & B & A \\
19-August & 5344 & B & A \\
29-July & 5277 & B & \\
05-August & 5209 & B & \\
12-August & 5209 & B & \\
\hline
\end{tabular}

Note: Means with the same letter are not significantly different.

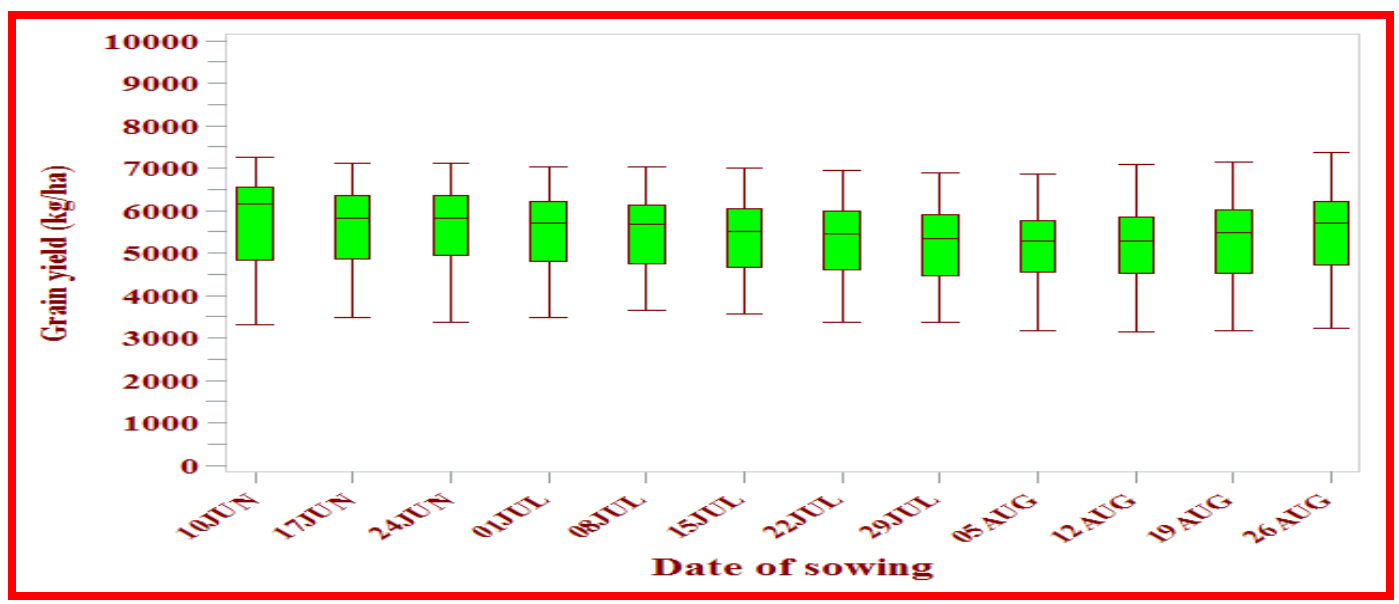

Fig. 1: Simulated grain yield of aerobic rice under variable sowing dates in irrigated conditions. Box limits represent the $25^{\text {th }}$ and $75^{\text {th }}$ percentiles, box central line represents the median, and outliers represent the minimum and maximum values. 
Table 2. Tukey's (HSD) test for mean grain yield $\left(\mathrm{kg} \mathrm{ha}^{-1}\right)$ of rice varieties under different dates of sowing under aerobic culture.

\begin{tabular}{|c|c|c|c|c|c|c|c|c|c|c|c|c|c|c|c|c|c|}
\hline \multirow{2}{*}{$\begin{array}{l}\text { Dates of } \\
\text { sowing }\end{array}$} & \multicolumn{2}{|c|}{ JGL 17004} & \multirow{2}{*}{$\begin{array}{l}\text { Dates of } \\
\text { sowing }\end{array}$} & \multicolumn{2}{|c|}{ MTU 1010} & \multirow{2}{*}{$\begin{array}{l}\text { Dates of } \\
\text { sowing }\end{array}$} & \multicolumn{5}{|c|}{ JGL 11470} & \multirow{2}{*}{$\begin{array}{l}\text { Dates of } \\
\text { sowing }\end{array}$} & \multicolumn{5}{|c|}{ MTU 1061} \\
\hline & $\begin{array}{l}\text { Grain } \\
\text { yield }\end{array}$ & $\begin{array}{l}\text { Tukey's } \\
\text { grouping }\end{array}$ & & $\begin{array}{l}\text { Grain } \\
\text { yield }\end{array}$ & $\begin{array}{l}\text { Tukey's } \\
\text { grouping }\end{array}$ & & $\begin{array}{l}\text { Grain } \\
\text { yield }\end{array}$ & \multicolumn{4}{|c|}{ Tukey's grouping } & & $\begin{array}{l}\text { Grain } \\
\text { yield }\end{array}$ & \multicolumn{4}{|c|}{ Tukey's grouping } \\
\hline 01-July & 4454 & A & 17-June & 5412 & A & 17-June & 6616 & & & A & & 10-June & 6697 & & & A & \\
\hline 24-June & 4449 & A & 24-June & 5402 & A & 24-June & 6463 & B & & A & & 17-June & 6521 & B & & A & \\
\hline 26-August & 4397 & A & 10-June & 5396 & A & 10-June & 6269 & B & & A & $\mathrm{C}$ & 24-June & 6435 & B & & A & $\mathrm{C}$ \\
\hline 17-June & 4362 & A & 26-August & 5360 & A & 26-August & 6201 & B & & A & $\mathrm{C}$ & 01-July & 6340 & B & $\mathrm{D}$ & A & $\mathrm{C}$ \\
\hline 08-July & 4361 & A & 01-July & 5331 & A & 01-July & 6193 & B & $\mathrm{D}$ & A & $\mathrm{C}$ & 08-July & 6211 & B & $\mathrm{D}$ & $\mathrm{E}$ & $\mathrm{C}$ \\
\hline 15-July & 4352 & A & 08-July & 5272 & A & 08-July & 6109 & B & $\mathrm{D}$ & & $\mathrm{C}$ & 26-August & 6118 & B & $\mathrm{D}$ & $\mathrm{E}$ & $\mathrm{C}$ \\
\hline 22-July & 4344 & A & 15-July & 5207 & A & 15-July & 6037 & B & $\mathrm{D}$ & & $\mathrm{C}$ & 15-July & 6107 & B & $\mathrm{D}$ & $\mathrm{E}$ & $\mathrm{C}$ \\
\hline 10-June & 4299 & A & 19-August & 5199 & A & 19-August & 5967 & & $\mathrm{D}$ & & $\mathrm{C}$ & 22-July & 6066 & & $\mathrm{D}$ & $\mathrm{E}$ & $\mathrm{C}$ \\
\hline 19-August & 4281 & A & 29-July & 5099 & A & 29-July & 5927 & & $\mathrm{D}$ & & $\mathrm{C}$ & 29-July & 5996 & & D & $\mathrm{E}$ & $\mathrm{C}$ \\
\hline 12-August & 4218 & A & 22-July & 5098 & A & 22-July & 5836 & & $\mathrm{D}$ & & & 19-August & 5930 & & $\mathrm{D}$ & $\mathrm{E}$ & \\
\hline 29-July & 4175 & A & 05-August & 5091 & A & 05-August & 5738 & & $\mathrm{D}$ & & & 05-August & 5865 & & & $\mathrm{E}$ & \\
\hline 05-August & 4141 & A & 12-August & 5074 & A & 12-August & 5732 & & D & & $\mathrm{C}$ & 12-August & 5814 & & & $\mathrm{E}$ & \\
\hline Mean & 4319 & & & 5245 & & & 6091 & & & & & & 6175 & & & & \\
\hline
\end{tabular}

Note: Means with the same letter are not significantly different. 


\section{Performance of varieties under aerobic conditions}

Simulation results of different varieties sown under aerobic conditions subjected to one way analysis of variance and means were compared with Tukey's HSD test and presented in the Table 2 and depicted in Fig. 2. Among the varieties tested, the long duration variety MTU 1061 found to be outstanding in terms of higher predicted median grain yield of $6175 \mathrm{~kg} \mathrm{ha}^{-1}$ and was closely followed by medium duration variety JGL 11470 with a median grain yield of $6091 \mathrm{~kg} \mathrm{ha}^{-1}$. The short duration cultivar MTU 1010 was moderate in term of predicted grain yield whereas, the extra sort duration variety JGL 17004 was found to be the lowest yielder. These results conforms the real time situation observed in two years experimentation.

\section{Optimum sowing window for extra short duration variety (JGL 17004)}

The simulation results predicted (Table 1) no significant difference in grain yield of extra short duration variety JGL 17004 across all the dates of sowing indicated that, this variety had a wider sowing window during kharif season.

However, the box plot (Fig. 3) showed that, $8^{\text {th }}$ July sown crop was considerably less variable than all other dates as the bottom whisker showed less risk of achieving low yields and upside whisker showed chances of achieving higher yields and consequently, smaller variance was associated to its average yield.

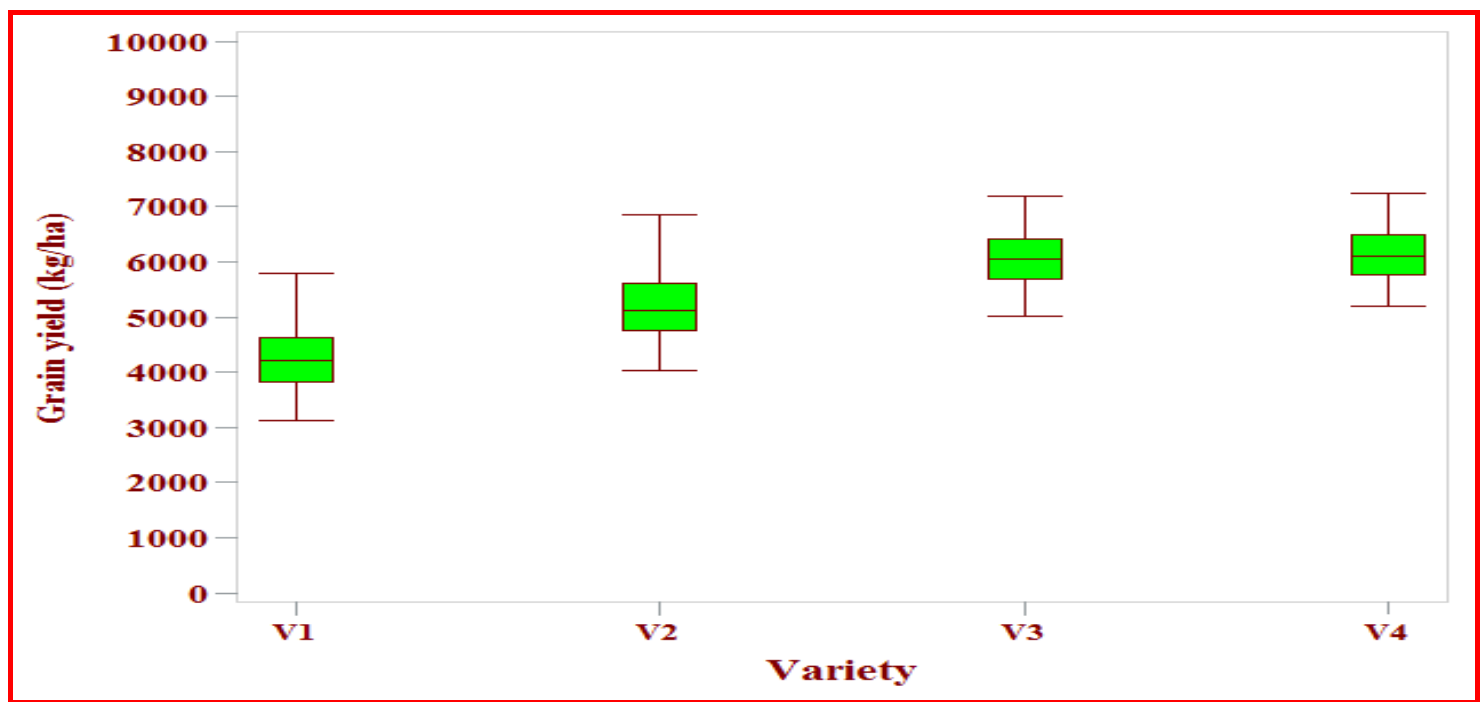

Fig. 2: Simulated mean grain yield of rice under variable sowing dates in aerobic irrigated conditions. Box limits represent the $25^{\text {th }}$ and $75^{\text {th }}$ percentiles, box central line represents the median, and outliers represent the minimum and maximum values.

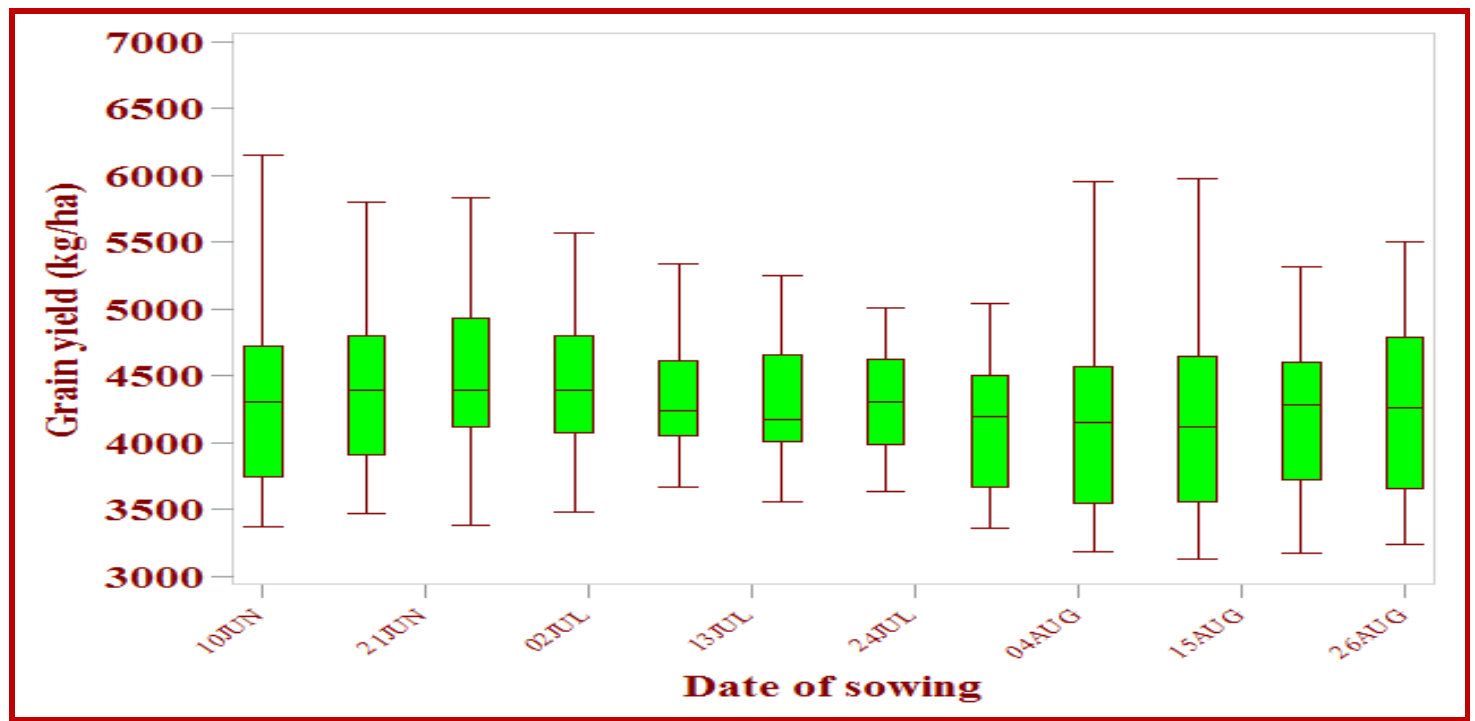

Fig. 3: Simulated mean grain yield of rice variety JGL 17004 under variable sowing dates in aerobic irrigated conditions. 


\section{Optimum sowing window for short duration variety (MTU 1010)}

As that of $c v$. JGL 17004, the simulation results also showed no significant difference in grain yield of MTU 1010across all the dates of sowing indicated that, this variety also had a wider sowing window during kharif season (Table 2). Further, the box plot (Fig. 4) showed that, $8^{\text {th }}$ July sown crop had less risk of achieving low yield followed by $1^{\text {st }}$ July sown crop. However, the median yield $\left(5272 \mathrm{~kg} \mathrm{ha}^{-1}\right)$ predicted with $8^{\text {th }}$ July sown crop was lower than the $1^{\text {st }}$ July $\left(5331 \mathrm{~kg} \mathrm{ha}^{-1}\right)$ sown crop. Further the projection of upside whisker relatively more and downside whisker slightly less with $1^{\text {st }}$ July sown crop when compared to $8^{\text {th }}$ July sown crop offers a choice to the grower to select either of the sowing date for achieving optimum yield.

\section{Optimum sowing window for medium duration variety (JGL 11470)}

The optimum sowing window for medium duration variety JGL 11470 considered from 10 June to $1^{\text {st July }}$ with the highest median grain yield $6616 \mathrm{~kg} \mathrm{ha}^{-1}$ predicted with $10^{\text {th }}$ June sown crop (Table 2). The model assumes that, there was no significant difference in grain yield of this variety from10th June to $1^{\text {st }}$ July sowing. However, a linear and significant reduction in grain yield was predicted from $8^{\text {th }}$ July onwards when compared to the grain yielded predicted with $10^{\text {th }}$ June sowing. These results indicated that, for medium duration variety, $10^{\text {th }}$ June to $1^{\text {st }}$ July would be the optimum sowing window to realize higher grain yield under aerobic environment. Further, the box plots (Fig. 5) showed that, 10 $0^{\text {th }}$ June sown crop producing higher median grain yield with less variable and risk of achieving lowest grain yield (down side whiskers) and higher chances of achieving more grain yield (upside whiskers) when compared to rest of the sowing dates which indicated that, for medium duration variety $10^{\text {th }}$ June sowing would be the best for achieving higher grain yield under aerobic culture.

\section{Optimum sowing window for long duration variety (MTU 1061)}

The simulation result of long duration $c v$. MTU 1061 was very close to the medium duration variety (JGL 11470). The optimum sowing window under aerobic culture for long duration variety considered from $10^{\text {th }}$ June to $1^{\text {st }}$ July with the highest median grain yield 6697 $\mathrm{kg} \mathrm{ha}^{-1}$ predicted with $10^{\text {th }}$ June sown crop (Table 2). The model assumes that, there was no significant difference in grain yield of this variety from $10^{\text {th }}$ June to $1^{\text {st }}$ July sowing. However, a linear and significant reduction in grain yield was predicted from $8^{\text {th }}$ July onwards when compared to the grain yield predicted with $10^{\text {th }}$ June sowing. These results indicated that, for long duration variety, $10^{\text {th }}$ June to $1^{\text {st }}$ July would be the optimum sowing window to realize higher grain yield under aerobic environment. Further, the box plots (Fig. 6) showed that, $10^{\text {th }}$ June sown crop producing higher median grain yield with less variable and risk of achieving lowest grain yield (down side whiskers) and higher chances of achieving more grain yield (upside whiskers) when compared to rest of the sowing dates which indicated that, for long duration variety $10^{\text {th }}$ June sowing would be the best for achieving higher grain yield under aerobic culture.

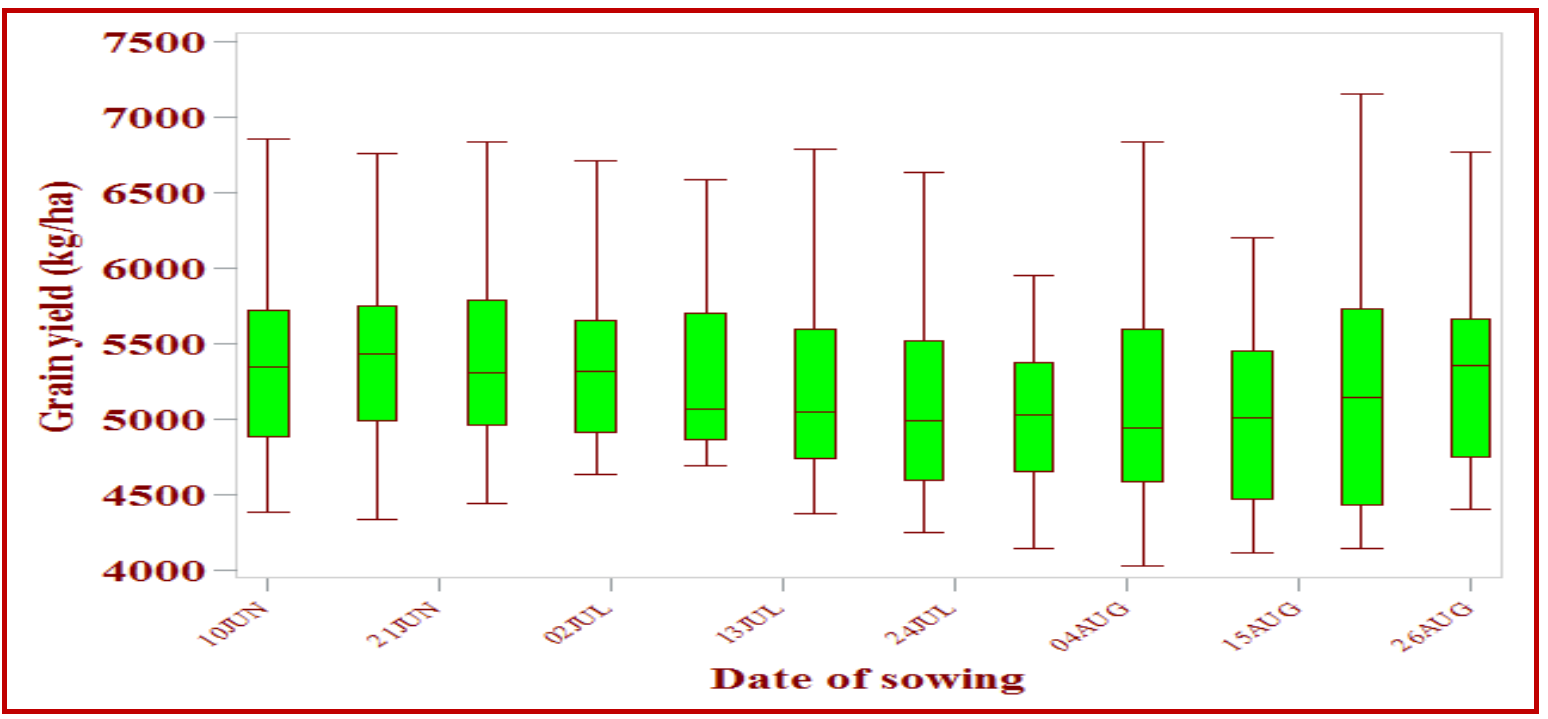

Fig. 4: Simulated mean grain yield of rice variety MTU 1010 under variable sowing dates in aerobic irrigated conditions. 


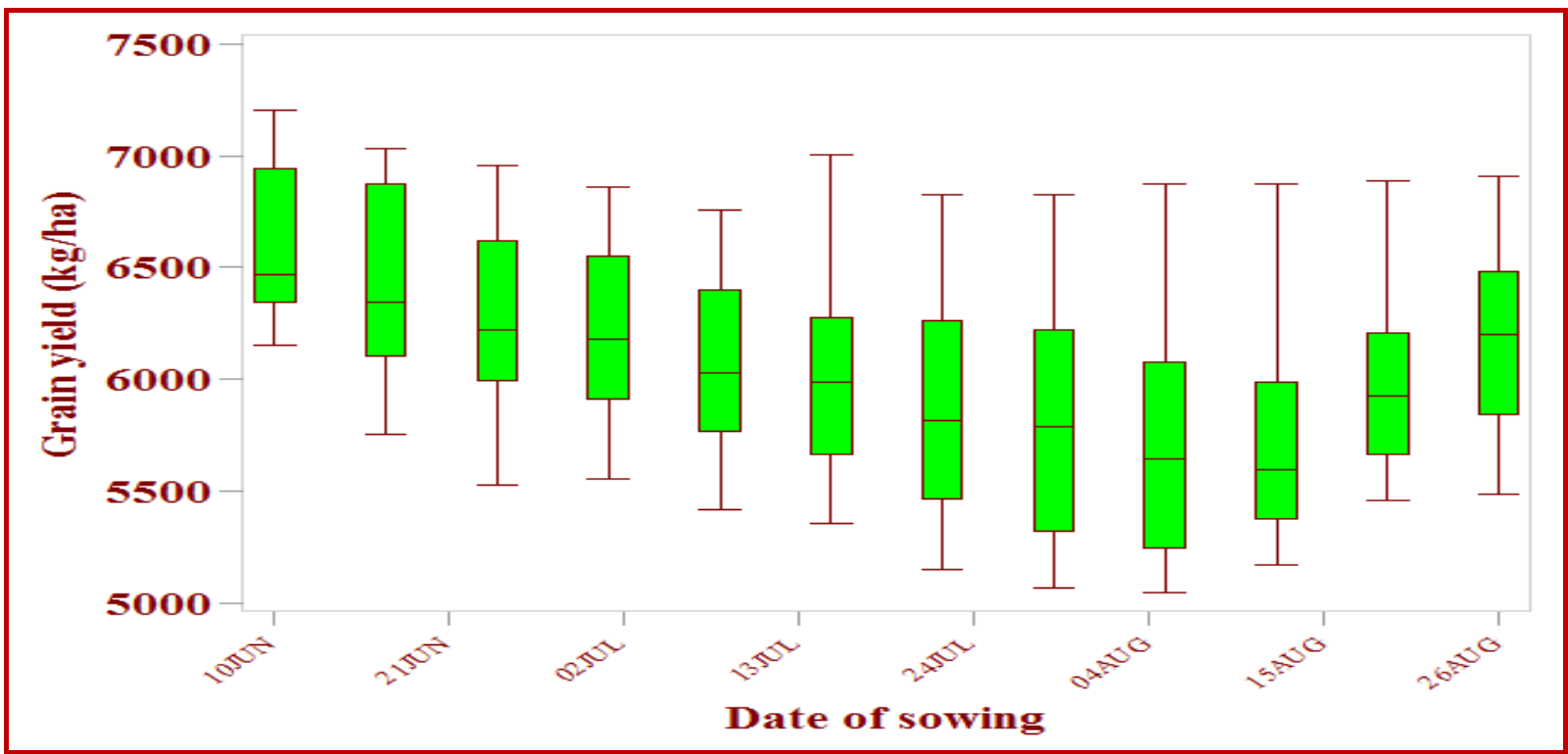

Fig. 5: Simulated mean grain yield of rice variety JGL 11470 under variable sowing dates in aerobic irrigated conditions.

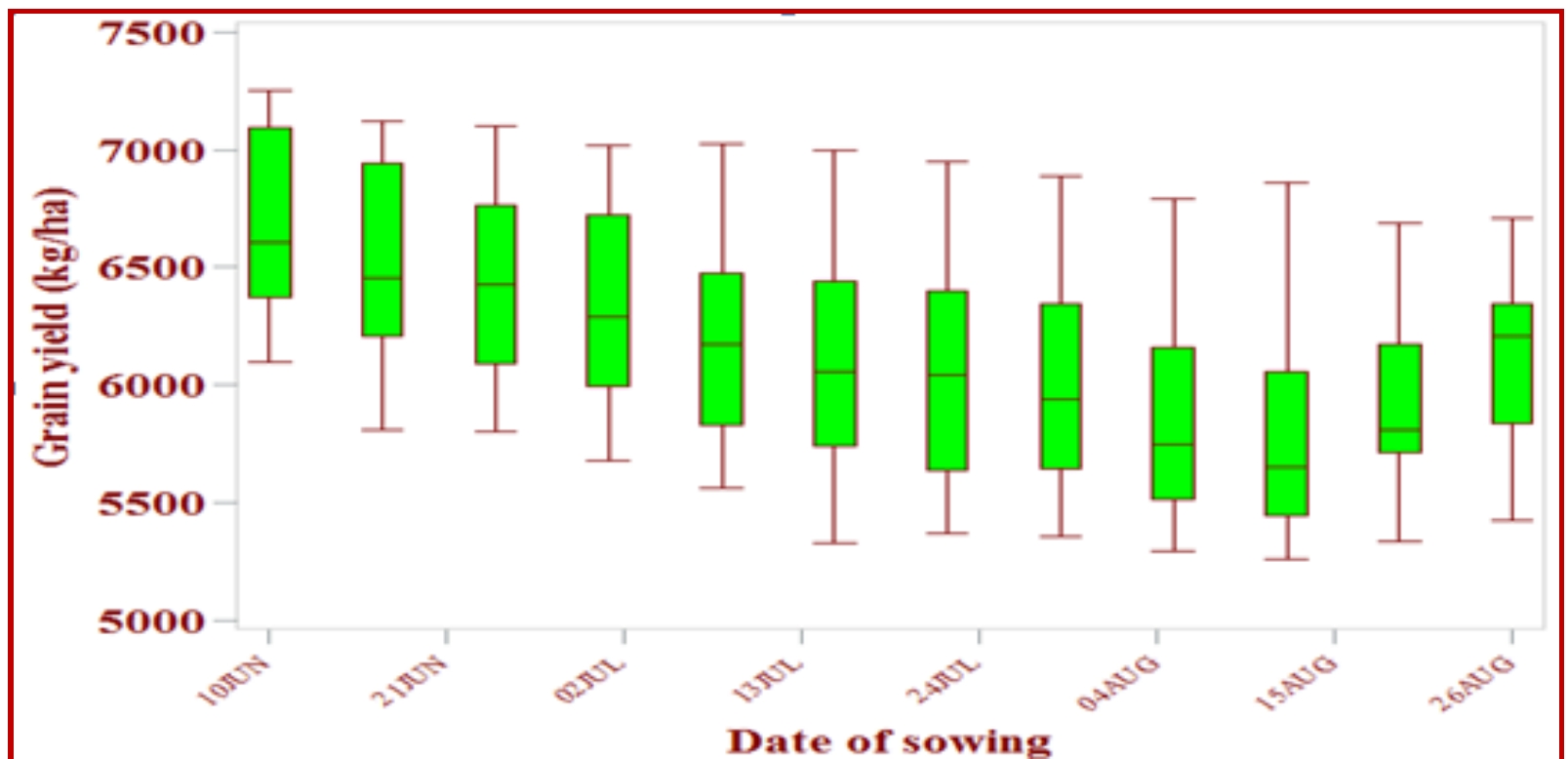

Fig. 6: Simulated mean grain yield of rice variety MTU 1061 under variable sowing dates in aerobic irrigated conditions.

\section{Conclusion}

From the above results, it can be concluded that, under irrigated aerobic conditions, $17^{\text {th }}$ June sown crop predicted the optimum grain yield con be realize by sowing the crop from $10^{\text {th }}$ June to $29^{\text {th }}$ June sown crop. The median yield decreased consistently with every one week delay in time of sowing. Among the varieties the extra short $c v$ JGL 17004 and short duration $c v$ MTU 1010 have wider sowing window from $10^{\text {th }}$ June to $26^{\text {th }}$ August whereas the medium duration $c v$ JGL 11470 and long duration $c v$ MTU 1061 have narrow sowing window from $10^{\text {th }}$ June to $1^{\text {st }}$ July.

\section{Conflict of interest statement}

Authors declare that they have no conflict of interest.

\section{Acknowledgement}

I (Banoth Balaji Naik) deem it as a great pleasure to express my heartfelt gratitude and respect to the chairman of my advisory committee, Dr. D. Raji Reddy, Director of Research, Prof. Jayashankar Telangana State Agricultural University, Rajendranagar, Hyderabad and Dr. G. Sreenivas, Director, Agro Climate Research Centre, Prof. Jayashankar Telangana State Agricultural 
University, Rajendranagar, Hyderabad, as a member of my Advisory Committee for his constructive criticism, learned counsel, meticulous guidance, encouragement in planning and execution of research work and affectionate treatment during the course of investigation and I profusely thank to Prof. Jayashankar Telangana State Agricultural University for providing me opportunity to pursue Ph.D. degree programme.

\section{References}

Andrade, C.L.T., Amaral, T.A., Silva, D.F., Garcia, A.G.Y., Hoogenboom, G., Guimaraes, D.P., 2009. Utilização do modelo CERES-maize comoferramentanadefinição de estratégias de semeadura de milho: 2 sistema de produçãoirrigado. In: CONGRESSO BRASILEIRO DE AGROMETEOROLOGIA, 6. Belo Horizonte. Mudançasclimaticas, recursoshídricos e energia parauma agricultura sustentavel. Resumos. Belo Horizonte: SBA; Viçosa, MG: UFV; SeteLagoas: EmbrapaMilho e Sorgo.

Bouman, B.A.M., Humphereys, E., Tuong, T.P., Barker, R., 2007. Rice and water. Adv. Agron. 92, 187-237.
Cocheme, J., Franquin, P., 1967. An agroclimatological survey of a semi-arid area in Africa, south of the Sahara. World Meteorol. Org. 86(210), TP 110.

Hayter, A. J., 1986. The maximum familywise error rate of Fisher's least significant difference test. J. Amer. Stat. Assoc. 81(396), 1000-1004.

Hittalmani, S., 2007a. Aerobic Rice Cultivation Brochure. MAS Lab, Univ. Agric. Sci., GKVK, Bangalore.

Hittalmani, S., 2007b. MAS946-1,A New Aerobic Rice Variety for Water Scarce Situation. Aerobic rice cultivation Brochure, MAS lab, Univ. Agric. Sci., GKVK, Bangalore.

Hunt, L.A., Boote, K.J., 1998. Data for model operation, calibration and evaluation. In: Understanding Options for Agricultural Production (Eds.: Tsuji, G.Y., Hoogenboom, G., Thornton, P.K.). Kluwer Academic Publishers, Dordrecht, The Netherlands. pp.9-39.

Snedecor, G.W., Cochron, W. G., 1967. Statistical Methods. Oxford and IBH Publishing Company 17, Parklane, Calcutta. pp.172-177.

Tuong, T.P., Bouman, B.A.M., 2002. Rice production in water scarce environments. In: Proceedings of the Water Productivity Workshop, 12-14 Nov. 2001. International Water Management Institute, Sri Lanka.

\section{How to cite this article:}

Naik, B. B., Sreenivas, G., Raji Reddy, D., Leela Rani, P., 2016. Application of CERES-rice model to identify optimum sowing window for different rice varieties under aerobic culture. Int. J. Curr. Res. Biosci. Plant Biol. 3(4), 75-82. doi: http://dx.doi.org/10.20546/ijcrbp.2016.304.012 